\title{
A Indenização do Fundo de Comércio nas Desapropriações
}

\author{
ARNOLD WALD \\ Advogado no Distrito Federal
}

\begin{abstract}
A
LGUNS acórdãos recentes têm estudado o problema da indenização do titular do fundo do comércia em caso de desapropriação por utilidade pública. Quando o fundo pertencia ao proprietário do prédio desapropriado, decidiram os tribunais incluir o seu valor na indenização que devia corresponder ao justo valor do imóvel. O problema se tornou mais complexo quando o titular do fundo do comércio era um inquilino, locatário do prédio desapropriado, não sendo pois parte no processo administrativo ou judicial de expropriação. Teria, neste caso, o comerciante direito a pedir uma indenização ao poder público pelos prejuízos sofridos? Ou apenas caberia no caso uma ação contra o proprietário do prédio que por sua vez poderia alegar a fôrça maior, o caso fortuito ou o fato de terceiro? E' esta questão que os nossos tribunais tiveram de dirimir.

O Supremo Tribunal Federal em acórdão publicado na Revista Forense, vol. 151 , pág. 159 , referente ao recurso extraordinário n. 9.557 , estabeleceu que deve haver o ressarcimento do dano sofrido pelo titular do fundo de comércio com a perda do seu estabelecimento e desvalorização do seu acêrvo. O Ministro Nelson Hungria, relator do feito, assinalou que:

"Se o bem comum não determina o sacrifício do direito do proprietário na desapropriação pois a lei lhe assegura indenização justa no expropriamento, que é realizado no interêsse coletivo, há de justificar que outro proprietário tenha o seu patrimônio desfalcado ou absorvido, no interêsse social, isto é que haja tratamento desigual, na lei, para os indivíduos?" (Revista Forense, volume 151, pág. 160).

Assim a indenização dos prejuízos sofridos pelo titular do fundo de comércio em caso de desapropriação já é matéria pacífica como o assevera outra decisão oriunda do Terceiro Grupo de Câmaras Cíveis do Tribunal de Justiça de Săo Paulo nos embargos à apelação n..$^{\circ} 66.646$ in Revista dos Tribunais, vol. 234, pág. 171 .
\end{abstract}


A jurisprudência que está assim consolidada se baseia no artigo 141 parágrafo 16 da Constituição Federal que garante " $\alpha$ direito de propriedade salvo o caso de desapropriação por necessidade ou utilidade pública, ou por interêsse social, mediante prévia e justa indenização em dinheiro".

Têm entendido todavia os nossos tribunais que quando o titular do fundo de comércio não é proprietário do prédio desapropriado não pode intervir no processo de desapropriação, só podendo acionar os poderes públicos em ação própria. Considera-se também que o titular do fundo não pode exigir o deposito da quantia que the é devida a título de indenização para que o poder público possa ser imitido na posse do prédio de acôrdo com o artigo 15 do decreto-lei n. ${ }^{\circ} 3.365$, de 21 de junho de 1941. A quantia depositada é pois sòmente aquela devida ao proprietário do prédio. O titular do fundo do comércio só poderá obter $\alpha$ pagamento da indenização que the é devida mediante açáo ordinária contra o poder expropriante devendo se sujeitar a tôdas as dificuldades que oferece o pagamento de uma indenização por parte do Estado.

Se a Constituição estabeleceu que a indenização em caso de desapropriação deve ser justa e prévia foi com a finalidade de dar um tratamento especial ao proprietário que perde os seus bens por motivo de utilidade ou necessidade pública. Atendeu-se ao imperativo de garantir a propriedade, fazendo com que a justiça só imitisse os poderes públicos na posse dos bens depois de depósito judicial da quantia arbitrada. Estendeu-se a indenização ao titular do fundo de comércio por ser êle também um proprietário e merecer pois a proteção legal. Embora seja um direito novo, a azienda ou fundo de ccmércio é cercado de garantias pela nossa legislação que, a partir de 1934, pelo decreto n. $^{\circ} 24.150$ de 20 de abril, assegurou o renovamento dos contratos de locação de imóveis destinados a fins comerciais ou industriais. Na exposição de motivos que precedeu o mencionado decreto, o legislador reconheceu "que o valor incorpóreo do Fundo de Comércio se integra em parte no valor do imóvel, trazendo desta arte pelo trabalho alheio benefícios ao proprietário", "que não seria justo atribuir exclusivamente ao proprietário tal quota de enriquecimento em detrimento, ou melhor, com o empobrecimento do inquilino que criou o valor", e "que uma tal situação valeria por um locupletamento condenado pelo direito moderno".

Pelos motivos expostos, decidiu-se, com tôda razão, indenizar os prejuízos sofridos pelo titular do fundo do comércio. Trata-se na realidade de um direito de propriedade digno da proteção legal que merece em virtude do texto constitucional do artigo 141 parágrafo 16 . Na realidade, mais um passo há de ser feito. Uma vez que se reconhece a propriedade do titular do fundo de comércio, é necessário lembrar que a indenização a que tem direito em caso 
de desapropriação há, ela também, de ser prévia. Se assim não fôsse, a lei trataria desigualmente duas categorias de proprietários. A indenização seria prévia para o proprietário do imóvel mas não o seria para o titular do fundo de comércio. A lei então não seria igual para todos e haveria violação do parágrafo primeiro do artigo 141 da Constituição que garante a igualdade de todos perante a lei. Para que tal igualdade seja respeitada e para que a indenização, em caso de desapropriação, seja justa e prévia, torna-se imperativo que a indenização a que tem direito o titular do fundo do comércio, possa ser calculada na ação de desapropriação. Além disso em caso de depósito pelos poderes públicos da quantia arbitrada a fim de obter a imissão na posse do imóvel, o depốsito haverá de abranger não só a quantia correspondente ao valor do imóvel como ainda a indenização devida ao titular do fundo do comércio. Se assim não fôr, estabeleceremos tratamentos diferentes em casos idênticos. Desde que reconheçamos, como o fazem os nossos tribunais, os direitos do titular do fundo do ccmércio, não há razão legal para que a indenização de proprietário do prédio seja prévia, atendendo-se ao dispositivo cơnstitucional, enquanto a indenização do proprietário do fundo de comércio será posterior à ordem judicial que concede aos poderes públicos a imissão na posse do imóvel desapropriado.

O depósito para fins de imisão de posse há de ser da quantia arbitrada, do máximo legal abrangendo pois o justo valor, ou seja o valor no mercado não só do prédiơ desapropriado como do fundo de comércio que perde com a desapropriação um dos seus elementos básicos especialmente protegido pela nossa lei que é o contrato de locação. O direito ao contrato de locação é um dos elementos constitutivos do fundo de comércio e tem a máxima importância. E' a que afirma Georges Riper no seu Traité de droit commercial (2.a edição, 1951, pág. 154). "Le droit au bail constitue, nous le verrons, un élément important, et parfois le plus important du fonds de commerce. C'est l'emplacement de l'exproitation qui assure la clientèle; il en est ainsi notament de toutes les bontiques de quartier. D'autre part, le loyer est une lourde charge, et, en temps de crise économique, risque d'écraser l'exploitation. Enfin l'installation matérielle est un élément du crédit du commerçant et l'intérêt des créenciers est en jeu".

O nosso direito constitucional não permitiu, salvo em casos especialíssimos, a desapropriação sem indenização prévia. Sòmente "em casc de perigo iminente, como em guerra ou comoção intestina, as autoridades competentes pođerão usar da propriedade particular, se assim o exigir o bem público, ficando, todavia, assegurado o direito a indenização ulterior" (art. 141 par. 16 in fine). E' um dispositivo legal de direito singular que não admite interpretação extensiva. Em todos os outros casos, a indenização deverá ser prévia. 
Sòmente assim não haverá espoliação do proprietário do bem desapropriado. Ora, não se pode negar que o fundo de comércio enfeixa direitos protegidos pela nossa legislação. E também neste caso a indenização há de ser prévia, ou seja, anterior à imissão na pcisse do prédio desapropriado porque, caso contrário, o titular do fundo de comércio perderia o seu bem sem indenização prévia, devendo aguardar o cálculo da indenização que the é devida em ação própria. Tal medida não se justifica. E' uma questão de coerência. Admitido o direito co titular do fundo do comércio à indenização, não há como torná-la posterior à imissão. Deve ser prévia segundo o ditame constitucional. E nesta direção, há de se orientar a nossa jurisprudência procurando atender aos interêsses sociais sem menosprezar os direitos individuais garantidos pela Lei Magna.

Numa primeira fase, reconheceu-se o direito do titular do fundo de comércic a uma indenização no caso de desapropriação. Mas considerou-se que devia ser uma ação especial o meio processual de alcançar tal finalidade. A evolução agora orienta-se para o cumprimento integral da norma constitucional que faz da indenização prévia a condição sine qua non da desaprapriação. Prévia também será pois a indenização do fundo de comércio existente no prédio desapropriado e em caso de divergência dos peritos, a quantia arbitrada pelo perito desempatador haverá de ser depositada judicialmente para que possam os poderes públicos obter a imissão na posse do imóvel já que, depois da imissão, o titular do fundo de comércio terá perdido um dos elementos substanciais do seu patrimônio, causando-se um prejuízo que haveria de ser previamente indenizado.

Tenho o consôlo de haver dado a meu país tudo o que me estava ao alcance: a desambição, a pureza, a sinceridade, os excessos de atividade incansável, com que, desde os bancos acadêmicos, o servi.

$$
\text { RUI BARBosa - Oração aos Moços. }
$$

